\title{
SOCIO-CULTURAL FEATURES OF CULTURAL TOURISM IN BULGARIA
}

\author{
Veselin PETKOV \\ Shumen University of Shumen \\ Episkop Konstantin Preslavski \\ Veselin9003@abv.bg
}

\begin{abstract}
The study examines an understudied side of the multirange aspects of the cultural tourism in Bulgaria. Sociocultural aspects have been viewed through their spatial-temporal logic, where tourism resources are predetermined by the "substrate" on which those resources develop. This is the so-called cultural landscape to which substantial attention has been paid in this study. On the other hand, the tourists' notion for a given tourist destination goes through their purely mental rethinking in a socio-cultural aspect - something we refer to as "geographical (tourist) image". The imagined geographies (geography of images) is considered a part of cultural geography, but in the same time it is a socio-cultural element of the tourist industry. The creation of the tourists' profile also includes socio-cultural elements: tourists - with their demographic, financial, emotional profile are part of all that. Those features are considered within the cultural tourism in Bulgaria only. Viewed through such a "prism", the socio-cultural features respond to many well-known cause-effect relations in cultural tourism wherever it is developed, while on the other hand, socio-cultural features are able to explain the common mistakes made in tourism planning.

The present study identifies specific examples related to the socio-cultural aspects of cultural tourism. For example, Shumen region is a territory full of "past". Its cultural landscape is formed as a result of centuries-old deposits of different cultures, most of all those are the first Bulgarian capitals. In the following period, the region was the spiritual center of Bulgaria. Community centers ("Chitalishte"), theaters and musical performances gave the appearance of the city lifestyle in more recent historical periods. These cultural features make the territory of the region quite specific in terms of cultural tourism on an international scale. This is how the cultural landscape which has been shaped without the efforts of the contemporary society, has transformed the territory into a unique area for practicing this type of tourism. On the other hand, the territory of the Rhodope Mountains, for example, is abundant with sites and artefacts from the time of the ancient Thracians. The cultural landscape in that region therefore would be different from that in the region of Shumen and would facilitate predominantly the development of archaeological tourism (as part of the cultural tourism) or religious tourism, while the tourist flow to those type of tourist sites will exhibit different socio-cultural characteristics compared to those featuring the tourist flow to Shumen region for example.
\end{abstract}

Key words: cultural tourism, landscape, image, socio-culture.

\section{Resumo}

O presente estudo pretende dar conhecimento sobre os aspetos multivariáveis do turismo cultural na Bulgária. O estudo identifica exemplos específicos relacionados com os aspectos socioculturais do turismo cultural. A região de Shumen é um território cheio de "passado". A sua paisagem cultural resulta de depósitos seculares de diferentes culturas, a maioria das quais correspondem às primeiras capitais búlgaras. No período seguinte, a região era o centro espiritual da Bulgária. Os centros comunitários ("Chitalishte"), os teatros e as apresentações musicais demonstram o estilo de vida da cidade em períodos históricos mais recentes. Essas características culturais tornam este território bastante específico em termos de turismo cultural à escala internacional. É assim que a paisagem cultural que foi moldada ao longo dos tempos, transformou o território numa área única para a prática desse tipo de turismo. Por outro lado, o território dos Montes Ródope é abundante em sítios e artefactos da época dos antigos trácios. Nesta região, a paisagem cultural será diferente da existente na região de Shumen e ajudará a desenvolver predominantemente o turismo arqueológico (como parte do turismo cultural) ou o turismo religioso. O fluxo turístico para este local turístico poderá exibir características socioculturais diferentes em comparação com aqueles que caracterizam o fluxo turístico para a região de Shumen.

Palavras-chave: turismo cultural, paisagem, imagem, sociocultural. 


\section{Introduction}

The development of the tourism sector (including cultural tourism) depends on different sociocultural characteristics, both of the environment and the tourist contingent itself. This paper examines the socio-cultural aspects of the second element - those of the tourist contingent. The development of a particular type of tourism in a given space is determined by the environment where tourism is developed. Tourism is, in turn, a product of the interaction between the natural environment and the cultural product of the society that inhabits that environment, and has left its specific social and cultural prints, thus creating the so-called cultural landscape.

On the other hand, the perceptions of each environment including the tourism environment is dependent on the individual perceptions of the tourists or the local residents. The images (as part of the society) we create for each landscape, are an important socio-cultural feature of cultural tourism. Main objective: defining the socio-cultural profile of tourists in Bulgaria

\section{Socio-cultural profile of tourists}

According to the definition of the European Program for the Impact of Cultural Tourism on Urban Resources and Economy (ALEKSIEVA. BOKOVA, 2013), cultural Tourism is a form of tourism focused on culture, the cultural environment, including the landscapes of the destination, values and styles of life, local heritage, arts, spectacles, traditions and the entertainment resources of the host community. Cultural tourism can include participation in cultural events, museum visits and meetings with the local.

It is important to note that cultural tourism is not a computable economic activity, but rather an activity that encompasses the experience of the visitors in a given place, experiencing something beyond their everyday life. Cultural tourism occupies about $20 \%$ of the world's tourism travel market and about $60 \%$ of the tourism market in Europe (ALEKSIEVA. BOKOVA, 2013),

The introduction of the concept of cultural tourism and its development is has to do with international institutions such as ICOMOS, which "operates" on behalf of the UNWTO. In the 1960s, tourism was understood as a way of life became a program of mutual acquaintance between Europeans, as well as an economic tool for the development of the European regions. That was the time when designing programs for cultural heritage, whose apogee - "The Days of Heritage" gained popularity in the 1980s. At that same time, the UN imposed new terminology (www.icomos.org, 10.10.2018r.)

to be used for expressing and indicating the differences, and introduced the speaking of ethnic differences as of cultural differences. Gradually, cultural differences become a universal value that has its own visibility. This visibility is ensured through the World Heritage List while later - through the development of a program for the preservation of "the living human treasures". 
Cultural tourism focuses on the differences in the ways of life and the opportunity to explore the "authenticity", experiencing other cultures, and so on. All these activities and practices at the international level have their economic and social aspects which are hard to separate, regulated or set for regulation by the political figures. In other words, cultural tourism is a continuation of the development of tourism - mutual acquaintance and searching for economic effects at the local level...

Formally in 1965, ICOMOS set the theme of cultural tourism, but later its place was constructed in the way of that it is regarded as opposition to mass tourism - the one associated with "destroys" the destinations, while cultural tourism is seen as the one that preserves them. In 1987, the UN and UNESCO announced a world-class decade of cultural development, with cultural tourism being a key tool, which should protect cultural values while ensuring good income. The tracking of ICOMOS's history is a history of the "image" and the "tool" called "cultural tourism" (www.icomos.org).

Along with researchers' criticisms of the gradual transformation of the concept of cultural tourism into something which only serves the legitimacy of international organizations such as UNESCO today, there is a gradual shift in the political sphere along with a transition from "universalism" to "difference". On the one hand, it is the recognition of the traditional and modern cultures, being equally valuable alongside the historical monuments, with the introduction of a specific value - that of "the intangible heritage" - most often related to performing arts such as singing, dancing, craftworks, etc. On the other hand, the expansion of the sphere of cultural tourism encompasses heritages which are beyond the concept of the Western Europeans (BORTOLOTTO 2007, quoted by ALEXIEVA, BOKOVA, 2013), something which is seen as a positive effect.

Today, the interest is focused on exploring the various forms of cultural tourism and concepts in a diverse national context, in the context of regional development of the world or of a particular country, etc. Without even a lengthy field study, the different emphasis in demand and supply, strategies and policies aimed at "cultural tourism" are clearly visible. Whether it is to deepen knowledge by visiting historic sites or visiting emotionally, visually or otherwise, whether it is directed towards the elitism of knowledge and experience or "passing" through an important and world-wide object.

The personal characteristics of the tourist gives clarity about the preferences for a certain type of tourism, gives the opportunity to build the so-called tourist profile, which facilitates the management of destinations and their proper planning. The tourist profile includes socio-cultural elements such as demographic parameters, educational and financial status, marital and gender structure of the tourist contingent. This is an important part of the analysis of the tourism industry.

According to Penerliev (2016), studying the tourists' behaviour - however varied it should be provides a prerequisite for making proper projection of the tourism industry. Studying tourists' behaviour is an activity that beyond those employed in tourism, requiring the involvement of psychologists, anthropologists, ethnographers, etc. The behaviour is part of the general characteristic of the personality, which has different dimensions. It may be positive or negative, conscious or unconscious, etc. Behaviour differs between different ethnic or ethnographic groups, depending on the geographic areas they inhabit, etc. An essential question in tourism studies is: Should we examine tourist behaviour and why? The natural answer of course is yes, because: it gives us an idea of the 
wishes of the tourists; directions for future action; enables us to spot our mistakes; to accurately predict and plan our future actions. Along with some general trends in the behaviour of tourists segmentation is also required depending on certain regional differences. For example, globally speaking, as far as the so-called Western Civilization is concerned, the main trends in the behaviour of tourists are limited to certain demographic, financial or ecological dependencies, which not necessarily applies to all tourists around the world.

The modern consumer of tourism and leisure worldwide has the following characteristics: they are the ideal tourist multi-user; for a certain period of time (e.g. one year) they perform various activities depending on the type of tourism being practiced; they have certain experience in tourism that allows them to assess tourist services and to choose the best value for money; they demand more because they are well-informed about the product as a whole and about the tourist destination itself; they know they are part of a supply market rather than a demand one, which make them quite flexible and inconsistent with regard to consumer criteria and selective in making tourism decisions; they seek truth, not promises; they require security and warranty for the purchase, although under certain circumstances they are also ready to accept surprises to a certain extent; they want to be more active as a confirmation of their individuality - not only do they participate in the experience, but they also choose the elements of that experience; they are looking for self-realization; they want to satisfy more of their emotional/spiritual interests because they are better educated; apart from the main product, they are also interested in the availability of additional programs; they divided their stay into parts; holidays are shorter but numerous, distributed throughout the year; they are tempered by various daily destinations and products, or exotic, adventurous trips involving long journeys; they retain their preference for traditional and relatively close destinations Penerliev (2016).

In addition, modern tourists seek more tourist products and packages; they increasingly seek a stay in the nature, adventure, exotics, risk and sports along with the classic products such as recreation, culture, culinary. They possess better awareness of environmentally friendly, sustainable use of natural resources, which they see as a balance between the natural landscape and urbanization, as well as the opportunity to enjoy all that intensively. Modern tourists look for new contacts with the local population. They want to be properly welcomed and hosted and to mingle into new environments. They use a variety of sources of information when choosing a tourist destination to visit, and the Internet becomes more and more dominant as a source of such information (PENERLIEV, M. 2016). The socio-cultural attitudes of the tourists practicing cultural tourism in Bulgaria according to Penerliev (2016) in a survey to tourists, are limited to:

- Men and women are distributed almost equally, with a slight prevalence of men (men - 54\%, women - 46\%). Forty-nine percent are between the ages of 36 and 55, 36\% - between 15 and 35 years; $73 \%$ are employed. The share of people with higher education is $68 \%$;

- cultural tourism enthusiasts of come mainly from Western Europe, the Balkan countries and Russia; $55 \%$ of cultural tourism practitioners have already been in Bulgaria before. They are here for an "adventure" holiday and are attracted mainly by the cultural-historical sights, the low prices and the nature; 
- Thirty-seven percent arrive via a travel agency. Approximately $2 / 3$ plan their trip a month or even 2-3 months in advance;

- A quarter of the respondents arrived in the country without prior reservation;

- the average number of overnight stays is 6.4 days, spend 80 euros per day per person on the average, or 458 euros per person for the whole stay.

According to the data shown in Fig. 1 it becomes clear that cultural tourism comes second as a preferred type of tourism, after sea tourism, which makes it the second most important type of tourism among those mentioned in the survey. We can assume that in Bulgaria most of the time sea tourism is combined with cultural-cognitive tourism - something undeniably proved in the Shumen region. Cultural tourism is followed by SPA, eco- and other types of tourism, while last but not least - golf tourism is also practiced.

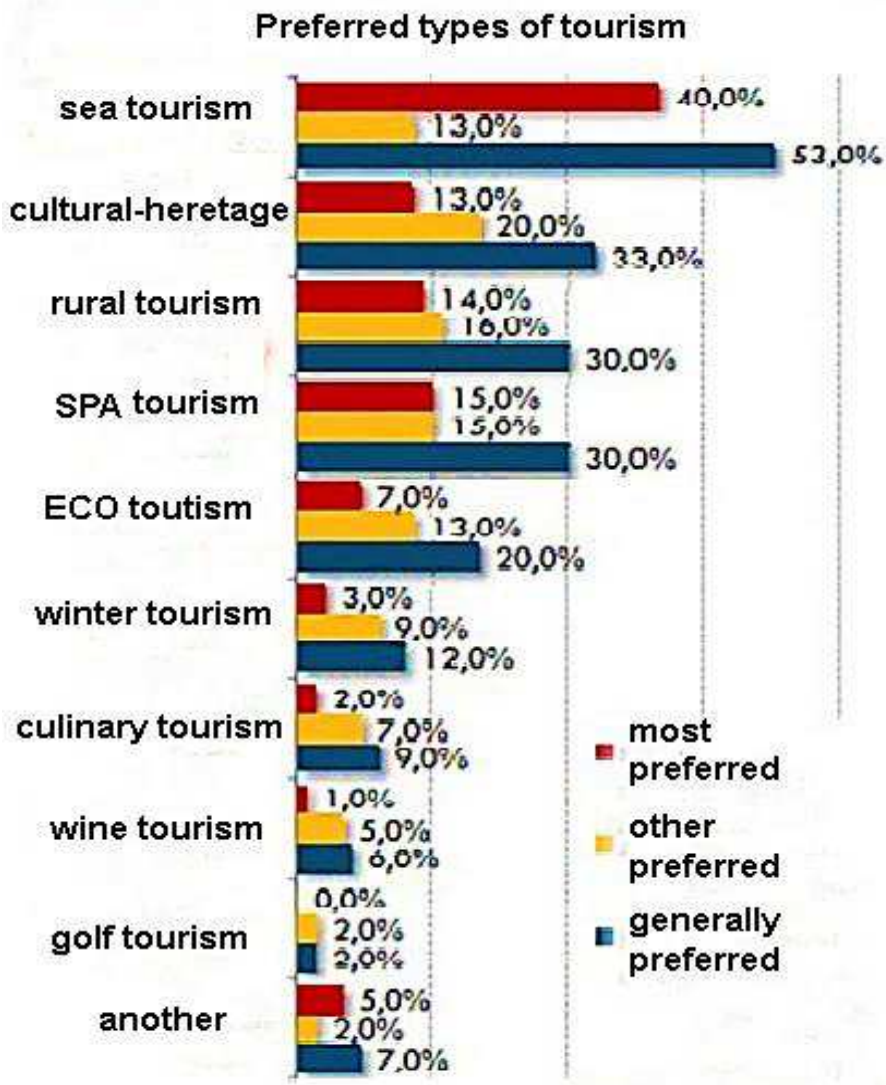

Figure 1 - Preference for practicing cultural tourism among tourists in Bulgaria (Source: http://www.mi.government.bg /13.10.2018г.)

As a result of the presented data and facts, it becomes clear that the description of the tourist contingents includes mainly socio-cultural elements such as behaviour, attitudes, desires, etc., together with basic features of the demographic structures of tourists (age, gender, educational level, etc.).

The main conclusions show that: 
- Cultural tourism practitioners come mainly from Western Europe, the Balkan countries and Russia;

- By sex, men and women are almost equally represented, with a slight prevalence of men;

- The average stay of a tourist is just over 6 days;

- About $70 \%$ of cultural tourism practitioners have higher education;

- Cultural-cognitive tourism is the second most important in Bulgaria.

\section{Socio-cultural features of the territory}

According to the Bulgarian dictionary, the term landscape (from German Landschaft) refers to a specific geographic territory which represents a system of all natural components (rocks, soil, air, water, vegetation and fauna) that change over time under the influence of natural factors and human activity. A synonym of the French paysage.

The term cultural landscape has been in use since the emergence of cultural geography (i.e. from the beginning of the 20th century). Cultural landscape refers to a natural-cultural complex formed under the influence of the combined impact of nature and man (Penerliev, 2017). Human society changes that landscape (pay sage) with its socio-cultural and economic activity. In 1932, a German scholar (Krebs) described the cultural landscape poetically as: Created over the natural landscape as a fine (or inappropriate) clothing on the body of man (PENERLIEV, PETKOV, 2017). In fact, the cultural landscape is the environment that surrounds us, altered by human activity under the influence of natural conditions, of the human's historical past, the religious and ethnic views and the result in specific culture. The architecture in a specific area differs from that of other cultural landscapes, so are lifestyles and livelihoods, which are different for different geographic territories even within a single country.

\section{Functional links between cultural landscape and cultural tourism}

Since the cultural landscape is a natural-cultural complex (see the definition above), it is composed of separate components (elements) that interact continuously as a system. The main elements of that system are: the natural landscape, the urban formations of the people, their economic activity, the language (including the toponymy ${ }^{1}$ of the geographic environment), the spiritual and intangible culture (mainly folklore) (Penerliev, Petkov, 2017) In fact, these are the elements that form the objects of the tangible and intangible cultural heritage. In the theoretical aspects of cultural tourism, those are the tourism resources that determine and develop it. This theoretical-methodological similarity is particularly important.

In fact, the cultural landscape as a category is the basis for the formation of most of the Bulgarian cultural heritage sites and is a cultural tourism resource - this is the case of the Old town of Nesebar, the Ivanovo Rock Monasteries, the Boyana Church, the Tsarevets Fortress, the Madara

\footnotetext{
${ }^{1}$ Toponymy: the science of names. Very often, the names of settlements and localities reflect the landscape utilized by humans.
} 
Horseman, etc. The combination of geographical location, the culture developed on the respective area and the objects built in a given area make it unique. Nesebar houses are not to be found anywhere else, even less so - along the Black Sea coast.

The cultural are may, to some point, replace the cultural landscape, but it rather complements the latter. For example, the cultural area which in a purely mental way emerges in our minds when talking about the Nestinar dances encompasses not just the village of Bulgari and the neighbouring ones, where Nestinar dancing is practiced, but the whole of the Strandzha mountain, as some mystic and extraordinary mountain. It is a custom that extends the scope of its cultural-geographical manifestation in our minds, although directly related to just a few settlements. The cultural area has wider mental areas than material. The cultural area of Bulgarian folklore is much wider than Bulgaria's geographic boundaries. This gives "expanse" to cultural tourism and development of tours beyond the borders of the country itself - in places where the Bulgarian element is preserved or should be preserved.

The cultural area and the cultural landscape in the context of cultural tourism define the "different" in the territory. In turn, that gives the territory different attractiveness and image. It is wellknown that the tourist is looking for something different from their own home or place of residence i.e. for a different and attractive cultural landscape (paysage).

The described elements of the cultural landscape form several types (including subtypes) of cultural landscapes, highlighting their differences. The division of cultural landscapes varies depending on the chosen leading criterion. According to Livinskaya (2014), cultural landscapes are divided into the following types:

1. A group of cultural landscapes that bear a valuable world or national cultural heritage. There are two subgroups in this group:

- cultural landscapes bearing the material (tangible) cultural heritage (archaeological monuments, architectural sites) as well as some natural phenomena.

- cultural landscapes, bearing intangible cultural heritage (lifestyle and culture of the local population), established by the local verbal folklore.

2. A group of cultural landscapes, established by scientific methods, which landscapes are valuable to the world in general or the region where they have been formed. They are also divided into two subgroups:

- cultural landscapes made up of real sites which represent objects of interest to scholars, folklorists, anthropologists and so forth. Those objects of interest may be the population itself (for example, isolated tribes in the Amazon basin), as well as historical monuments of ancient cultures.

- cultural landscapes based on mythology, religion, folk art, etc. Those cultural landscapes can be real (e.g. the Shopluk region in Bulgaria) or virtual (e.g. the undiscovered mythical continent of Atlantis). In fact, all Greek mythology and its development onto the natural landscape, namely - the Mount Olympus, is an example of a virtual landscape formed in our consciousness based only on myths and legends.

3. Cultural landscapes occurring only in the minds of artists (painters, musicians, authors). Though hard to understand and too abstract for us, these are the landscapes described in most 
fantasy novels (e.g. the environment where Harry Potter lives). Naturally, these types of landscape are not the subject of this study.

Thus described, cultural landscapes are formed on the basis of their predetermined natural resources (resulting from the natural landscape) or the presence of cultural values and cultures in their territories. If we define landscapes according to their outward appearance, then their division will look in a different way. As early as 1942, the prominent Bulgarian geographer Prof. Ignat Penkov argues that cultural geography studies the cultural landscape in its economic, urban and communicational aspect. Thus the above-mentioned author actually tries to divide cultural landscapes according to their appearance. Today, the overall opinions are similar. Most modern geographers distinguish:

- agricultural landscape

- rural cultural landscape

- industrial cultural landscape

Some of the authors (Livinskaya, Mitin, 2014 etc.) supplement this idea with religious (sacral), recreational, reservation (including cultural archaeological reserves), memorial (e.g. Arlington National Cemetery near Washington, D.C., military cemeteries of Bulgarian soldiers in Northern Dobrudzha) and other cultural landscapes.

The described types (subtypes) of cultural landscape are nothing more than the various resources for the development of cultural tourism in its variations (festival, literary, archaeological, adventure, industrial, scientific, etc.). Knowledge of the nature that determines those types of tourism facilitates the perceptions of their development, functioning and management. This comes to prove that the cultural landscape is the "substrate" of cultural tourism.

An interrelation has been established between the cultural tourism sites and the cultural landscape - the latter being the "substrate" (the environment) where those sites have been formed. The study of both is carried out by following the same algorithm and using similar methods. Scientific research is important for the preservation of the cultural landscape (the tourism resources for cultural tourism).

The cultural-geographic environment only becomes a fact after a certain time period of formation and modeling. That environment is definitely attached to a particular territory. The genetic approach is often applied in the study of cultural-geographic environment. This is a general scientific method that aims to explain the different processes and phenomena occurring in the environment in the context of the "time" category. The genetic approach is an important method for determining conservation and management actions concerning the intangible cultural heritage. For example, when analyzing the custom of "Surva" or the Koprivshtitsa fair, it is important to define the historical-temporal framework of their emergence and development, as well as the cultural-geographical area that the custom covers. The protection of such heritage is not only conceived in its annual presentation to guests or tourists (in the case of the Koprivshtitsa fair- held every four years). Both are examples of gathering activities and customs from a much larger territory than the place of their manifestation. These are customs that are not attached to a specific geographic environment. Therefore, their preservation requires not only their organization, but also activities such as: 
- Mapping the locations of their main manifestations;

- Identification of the spatial cultural-geographic differences;

- Justification of the historical reasons that have led to such differences, using the methods of analysis of the cultural landscape;

- Based on the above, the most urgent activities for the preservation and conservation of those customs and folklore peculiarities can be identified.

Protecting the local cultural landscape is mandatory, considering that identity preservation is a top priority. Kuker masks and games exist not just in Bulgaria but also in Serbia, Italy, Spain and elsewhere. Therefore, the local uniqueness should be the distinctive feature. In this context, the Bulgarian cultural-geographic identity should be sought and protected.

In the light of the above theses, the intersections between cultural tourism sites and cultural landscape are indisputable. In fact, these are identical areas and sites, merely viewed from different angles.

\section{Socio-cultural features of tourism resources}

The continuous improvement of the definitions of cultural tourism, focusing on one or other aspect of the concept, has been brought together by Zheleva-Martins (2005). Author of some of the most famous definitions of cultural tourism: a journey undertaken by somebody with the intention of enriching their ideas about the cultural values of Europe" (ATLAS)"; "travelling of people to cultural attractions away from their permanent residence, in order to gather new information and experience to satisfy cultural needs"; "any travelling of people to specific cultural attractions such as: historical sites, artistic and cultural events, arts and drama, outside their permanent residence" (JELEVA-MARTINIAS, 2005). Marin Neshkov has complemented that last "working definition" of cultural tourism focusing on the consumption of goods originating in a definitive cultural context of the tourism resources and products, as well as a specific niche of tourism demand and a particular part of the tourism industry (Penerliev, 2017).

It is interesting to extend the concept of "cultural tourism", which, according to another author, means all trips to cultural-historical sites and acquiring knowledge of the cultural heritage of a given destination, which includes architecture, performing and visual arts, way of life of the local population, local traditions and beliefs "(MARINOV, 2011) In the context of the new dimension of cultural tourism, Marinov emphasizes that in the $20^{\text {th }}$ century embodies the ideas of the intellectual and moral solidarity of mankind, and is defined as one of the most promising variations of the tourism industry which facilitates the exploration, the studying andthe comparing ofnations' cultural heritage.

International tourism helps the world economy and politics not only as the most applicable means of cultural exchange. It is a recognized resource for building and maintaining national and regional identity and cultural diversity. An argument for the preservation of this diversity in Bulgaria is a precisely formulated goal in the "Cultural Tourism Charter" for the Management of the Natural and 
Cultural Heritag, which Europe preserves: giving publicity to its importance for society and the need to preserve it.

The preservation of the tangible and intangible heritage requires the personal commitment and empathy of the successors of Bulgarian history, culture and traditions. Both cultural tourism and the image of the country itself will benefit given that investment and entity, responsibility and vision, advertising and communications, information technologies and interactivity are united into a single entity (ALEXIEVA, 2010).

The development of one of the most interesting types of tourism, however, is not only a function of the advantages of a given tourist destination and its cultural and natural heritage. At the heart of the creation and professional promotion of the cultural tourism product is the activity of numerous working cultural institutions, various tourist companies and agencies, and last but not least - the use of specialized companies for integrated marketing and communication in so as to multiply the advantages of new technologies and of the new media to attract new customers and create an image and recognition in an increasingly competitive tourism market.

It is a well-known fact that the cultural-historical heritage of Bulgaria is heavily concentrated in certain regions where the cities have always had real chances for professional development of cultural tourism. Those regions have traditionally offered a wide variety of tourist products, motivated by the need of tourists to enrich and expand their general and specialized knowledge. Because of the diversity of cultural tourism, these cities attract "diverse forms or nuances: cultural, recreational, educational, scientific, etc. A typical feature of cultural tourism in general is its universality, which means it can be combinedwith almost any other type of tourism (NESHKOV, 2007).

The criteria used for the division of cultural tourism, however, are different according to the researchers. For the classification of the different types of cultural tourism, a wide variety of elements is taken into consideration, such as: cultural and historical monuments; architectural sites; ethnographic complexes, monastery complexes and churches; museums and monuments; different cultural attractions; national parks; gardens and reserves; industrial heritage, etc.

According to some researchers, one of the criteria used in the contemporary classification of cultural tourism is the so-called same-rank unity (being of the same rank) of the socio-cultural needs and the cultural attraction while (...) the individual types and forms of cultural tourism manifest themselves in a certain cultural environment (KOSTOV, 2001). On the basis of this criterion, the following categories of cultural tourism are used in the specialized literature: religious (educational religious tourism, pilgrimage, missionary, festival religious tourism); educational (congress, field trips, industrial); festival (festivals of various arts: cultural holidays, festivals of traditional national products); cultural tourism related to the cultural-historical heritage (historical and architectural monuments, museums and galleries). These, among other subtypes of cultural tourism complement its main purposes, such as cultural-cognitive and educational; conservation and heritage preservation; communicational function, etc.

In such dynamic and successful and yet controversial times for world tourism development, the change of consumer attitudes and the new expectations for cultural tourism, complement the travel motivation of the tourists. According to the official documents of leading international organizations, 
culture is increasingly seen as a resource for building and maintaining local, national and regional identity, as well as cultural diversity. The definition of the termculture has been expanding continuously, thanks to the acknowledgement that popular culture, such as music, movies and even sports, can also be regarded as a part of the definition of culture. There is much evidence that the market is expanding due to the growing interest in culture among consumers.

\section{Conclusion}

The main reason for the increasing demand is the growing educational level. New consumers of cultural tourism come from regions such as Central and Eastern Europe and Asia, where education and personal health have been improving. The motivation for cultural tourism has been slowly changing towards more general interests in culture, rather than towards more specific cultural purposes. This implies the need to combine cultural, leisure and leisure-related products in the future (PARUSHEVA, 2010).

This shift other perception of both culture and tourism, together with the natural broadening of the boundaries of cultural heritage, are part of the understanding how diverse cultural heritage can be. Because exploring this heritage is not just about some specific history - In the globalizing world, an increasing number of nations and communities are looking for their roots, looking for some support to their identity. When people know their history and what they have inherited, they become more tolerant to others, they feel more like citizens of the world (PENERLIEV, 2016). It is exactly that change in the understanding of cultural heritage, together with the enrichment of concepts, which turn centuries-old traditions into a basis of the modern society and change its views on the combination of monuments and their messages today. At the same time, however, the changes that globalization inevitably provokes in the lifestyles of modern societies, having a strong influence on the motivation and prerequisites for the development of cultural tourism, should not be underestimated. On the one hand, despite its proven potential for successful development in our country, a "realistic and balanced approach" is needed. On the other hand, however, while being un constrained by "seasonality", cultural tourism requires significantly higher investments compared to other types of tourism. By creating real opportunities for sustainable tourism, along with higher revenues, higher expectations and more effective reflections on Bulgaria's positive image as a tourist destination, cultural tourism also implies a higher risk against the background of the aggressively growing competition in the supply of cultural tourism.

\section{Bibliography}

1. ALEKSIEVA. S..I. BOKOVA (2013), Turizmyt i kultutnoto nasledstvo, izd. NBU, (in bulgarian)

2. KOSTOV, E. (2001). Kulturen turizam, (in bulgarian)

3. LIVINSKAYA, O. A. Ponyatie kulturen landshaft $v$ otechestvenoy geografii, 2014, (in russian) 
4. PENERLIEV, M., V. PETKOV. (2017), Sbornik uchebni materiali po kulturna geografia, Shumen (in bulgarian)

5. PENERLIEV, M. (2016), Izsledvane na turisticheskoto povedenie I profila na turistite v Bulgaria, Sb. Nauchna konferenciya Geografski aspekti na planiraneto I izpolzvaneto na teritoriyata v usloviya na globalni promeni, gr. Varshec, (in bulgarian)

6. PENERLIEV, M. (2016), Turizmyt - syvremenni teoretichni aspekti, izd. SHU, Shumen, (in bulgarian)

7. PENERLIEV, M. Cultural landscape: the "substrate"of cultural tourism, Journal Sociobrains (www.sociobrains.com), issue 38, October 2017

8. ZHELEVA-MARTINS, D. (2005), Kulturen turizam, (in bulgarian)

9. http://www.mi.government.bg (13.10.2018r.)

10. http://www.nsi.bg (20.09.2018г.)

11. www.icomos.org (10.10.2018г.) 